\title{
Bone Marrow Donation
}

National Cancer Institute

\section{Source}

National Cancer Institute. Bone Marrow Donation. NCI Thesaurus. Code C64258.

Traditionally, minor surgery to draw marrow from the hipbones followed by collection of the stems cells from the donated marrow. Today the most common way of collecting the stem cells is by filtering them directly from the blood. Although this procedure is technically called peripheral blood stem cell donation, it is still commonly referred to as bone marrow donation. 